\title{
Teaching Video NeuroImages: Horizontal gaze palsy with progressive scoliosis
}

Hee Kyung Yang, MD, Jeong-Yoon Choi, MD, Kyung Seok Park, MD, Jae Hyoung Kim, MD, and Jeong-Min Hwang, MD

Neurology ${ }^{\circledR}$ 2019;92:e886-e887. doi:10.1212/WNL.0000000000006962

A 10-year-old girl presented with abnormal eye movement since birth. She was born from consanguineous parents. Ocular ductions showed complete horizontal gaze palsy, partial limitation of upgaze, and synergistic convergence (figure, A; video). Her pupils were round and isocoric. She showed severe thoracolumbar scoliosis. Uncrossed corticospinal and dorsal column-medial lemniscal pathways were demonstrated during intraoperative neuromonitoring of scoliosis surgery. Brain MRI revealed a bifid shape of the pons and medulla oblongata (figure, $\mathrm{B}-\mathrm{D})$, which is a typical finding of horizontal gaze palsy with progressive scoliosis. ${ }^{1,2}$ Bilateral oculomotor, trochlear, and abducens nerves were normally identified (figure, E).

\section{Study funding}

No targeted funding reported.

\section{Disclosure}

The authors report no disclosures relevant to the manuscript. Go to Neurology.org/ $\mathrm{N}$ for full disclosures.

\section{Appendix Authors}

\begin{tabular}{llll}
\hline Name & Location & Role & Contribution \\
\hline $\begin{array}{l}\text { Hee Kyung } \\
\text { Yang, MD }\end{array}$ & $\begin{array}{l}\text { Seoul National } \\
\text { University }\end{array}$ & Author & $\begin{array}{l}\text { Designed and conceptualized study, major role in the acquisition of } \\
\text { data, analyzed the data, drafted the manuscript for intellectual } \\
\text { content }\end{array}$ \\
$\begin{array}{l}\text { Jeong-Yoon } \\
\text { Choi, MD, }\end{array}$ & $\begin{array}{l}\text { Seoul National } \\
\text { University }\end{array}$ & Author & $\begin{array}{l}\text { Major role in the acquisition of data, Interpreted the data, drafted the } \\
\text { manuscript for intellectual content }\end{array}$ \\
$\begin{array}{l}\text { Kyung Seok } \\
\text { Park, MD }\end{array}$ & $\begin{array}{l}\text { Seoul National } \\
\text { University }\end{array}$ & Author & Interpreted the data, revised the manuscript for intellectual content \\
$\begin{array}{l}\text { Jae Hyoung } \\
\text { Kim, MD }\end{array}$ & $\begin{array}{l}\text { Seoul National } \\
\text { University }\end{array}$ & Author & Interpreted the data, revised the manuscript for intellectual content \\
$\begin{array}{l}\text { Jeong-Min } \\
\text { Hwang, MD }\end{array}$ & $\begin{array}{l}\text { Seoul National } \\
\text { University }\end{array}$ & Author & $\begin{array}{l}\text { Designed and conceptualized study, analyzed the data, revised the } \\
\text { manuscript for intellectual content }\end{array}$ \\
\hline
\end{tabular}

\section{References}

1. Bosley TM, Salih MA, Jen JC, et al. Neurologic features of horizontal gaze palsy and progressive scoliosis with mutations in ROBO3. Neurology 2005;64:1196-1203.

2. Jen JC, Chan WM, Bosley TM, et al. Mutations in a human ROBO gene disrupt hindbrain axon pathway crossing and morphogenesis. Science 2004;304:1509-1513.

\section{Correspondence}

Dr. Hwang

hjm@snu.ac.kr

\section{MORE ONLINE}

- Video

$\rightarrow$ Teaching slides

links.lww.com/WNL/

A818

From the Departments of Ophthalmology (H.K.Y., J.-M.H.), Neurology (J.-Y.C., K.S.P.), and Radiology (J.H.K.), Seoul National University College of Medicine, Seoul National University Bundang Hospital, Seongnam, South Korea.

Go to Neurology.org/N for full disclosures. 

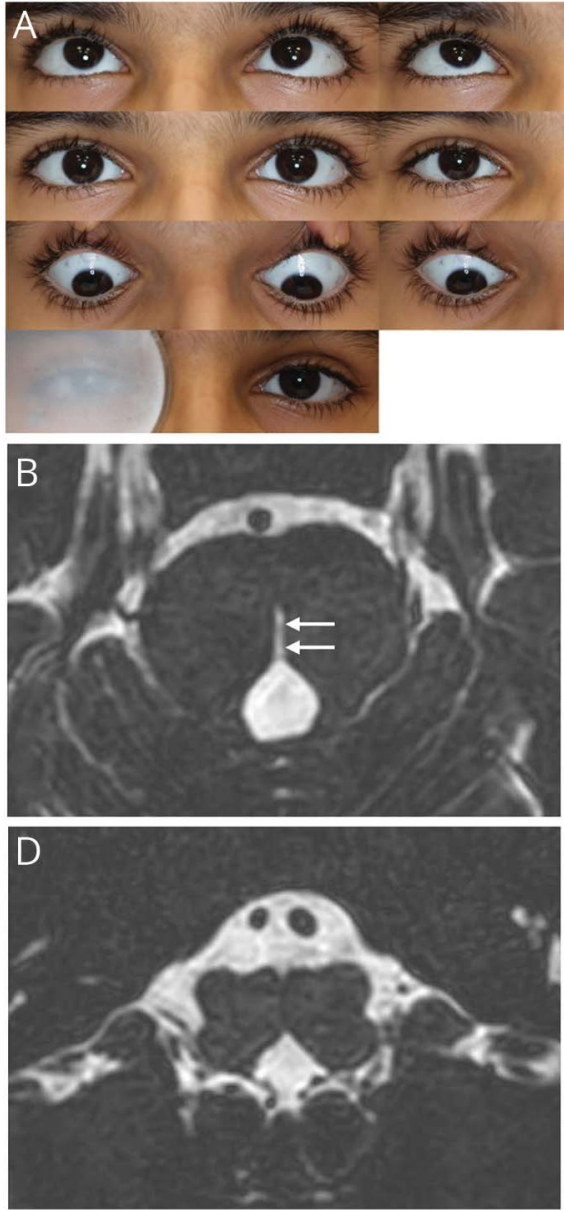
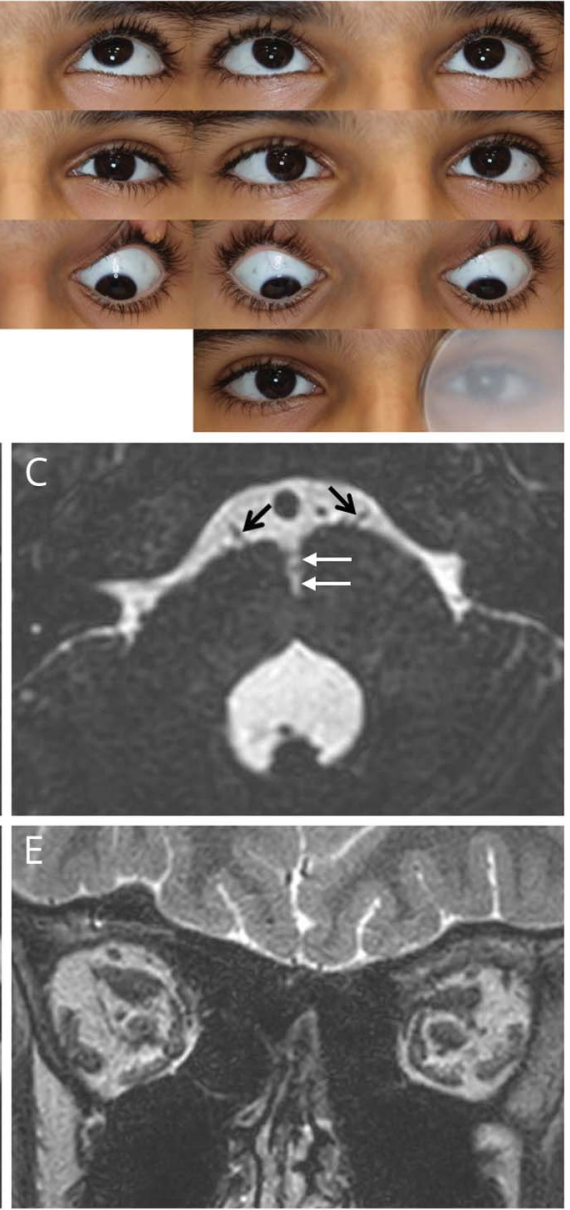

(A) Nine gaze photographs of the patient show horizontal gaze palsy. Both eyes show complete limitation of horizontal eye movements during right gaze (left column, second row) and left gaze (right column, second row). A partial limitation of upgaze is also noted (middle column, first row). (B, C) T2-weighted images show a bifid shape of the pons with a midline fissure (white arrows) at mid and lower levels. Both abducens nerves are normal (black arrows). (D) Butterfly shape of the upper level of medulla oblongata. (E) Normal extraocular muscles. 


\section{Neurology}

Teaching Video NeuroImages: Horizontal gaze palsy with progressive scoliosis Hee Kyung Yang, Jeong-Yoon Choi, Kyung Seok Park, et al.

Neurology 2019;92;e886-e887

DOI 10.1212/WNL.0000000000006962

This information is current as of February 18, 2019

\section{Updated Information \&} Services

References

Subspecialty Collections

Permissions \& Licensing

Reprints including high resolution figures, can be found at: http://n.neurology.org/content/92/8/e886.full

This article cites 2 articles, 2 of which you can access for free at: http://n.neurology.org/content/92/8/e886.full\#ref-list-1

This article, along with others on similar topics, appears in the following collection(s):

All Clinical Neurology

http://n.neurology.org/cgi/collection/all_clinical_neurology

All Genetics

http://n.neurology.org/cgi/collection/all_genetics

All Movement Disorders

http://n.neurology.org/cgi/collection/all_movement_disorders

Developmental disorders

http://n.neurology.org/cgi/collection/developmental_disorders

Ocular motility

http://n.neurology.org/cgi/collection/ocular_motility

Information about reproducing this article in parts (figures,tables) or in its entirety can be found online at:

http://www.neurology.org/about/about_the_journal\#permissions

Information about ordering reprints can be found online:

http://n.neurology.org/subscribers/advertise

Neurology ${ }^{\circledR}$ is the official journal of the American Academy of Neurology. Published continuously since 1951, it is now a weekly with 48 issues per year. Copyright @ 2019 American Academy of Neurology. All rights reserved. Print ISSN: 0028-3878. Online ISSN: 1526-632X.

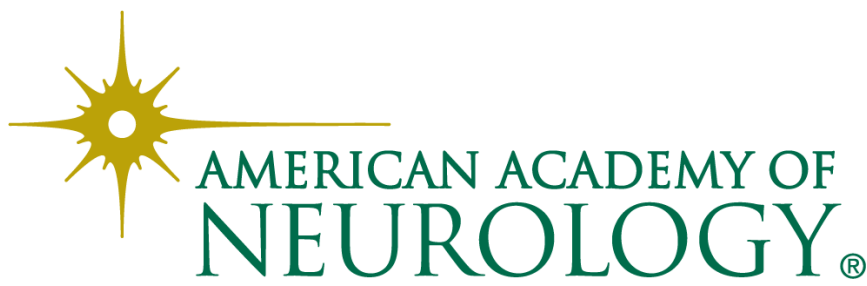

